\title{
Serum Growth Hormone and Insulin-Like Growth Factor-1 Concentrations in Japanese Black Cattle with Renal Tubular Dysplasia
}

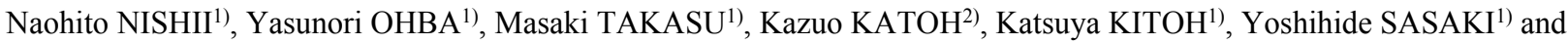 \\ Hitoshi KITAGAWA ${ }^{1) *}$ \\ ${ }^{1)}$ Laboratory of Veterinary Internal Medicine, Department of Veterinary Medicine, Faculty of Applied Biological Sciences, Gifu \\ University, 1-1 Yanagido, Gifu 501-1193, and ${ }^{2}$ Department of Animal Physiology, Graduate School of Tohoku University, Tsutsumidori- \\ Amamiyacho, Sendai 981-8555, Japan
}

(Received 11 May 2004/Accepted 7 December 2004)

\begin{abstract}
To elucidate the cause of growth retardation, 14 cattle with renal tubular dysplasia (RTD) were investigated by determining serum growth hormone $(\mathrm{GH})$ and insulin-like growth factor (IGF)-1 concentrations. Compared with 6 healthy cattle, the baseline, maximum, area under the curve and peak amplitude of serum GH concentrations were higher or tended to be higher. Serum IGF-1 concentrations were lower normal or lower in cattle with RTD than in healthy cattle. Serum IGF-1 concentrations correlated significantly with body weight and chest girth, but not with serum GH and creatinine concentrations. Growth retardation in RTD might be associated partially with GH resistance.
\end{abstract}

KEY WORDS: growth hormone, growth retardation, IGF-1, Japanese black cattle, renal tubular dysplasia.

J. Vet. Med. Sci. 67(4): 399-402, 2005

The growth of animals is controlled by hormones and growth factors such as growth hormone $(\mathrm{GH})$, insulin-like growth factor (IGF)-1, thyroid hormones, sex hormones, insulin, and glucocorticoids [22]. Among these physiologically active substances, GH and IGF-1 plays an essential role $[4,10,14]$. Renal tubular dysplasia (RTD) is an autosomal recessive hereditary disease in Japanese Black cattle [18, 19], characterized clinically by growth retardation, overgrowth of hooves, and chronic renal failure (CRF). In human patients with CRF, growth retardation is a serious clinical problem, together with other signs such as metabolic acidosis, malnutrition, renal osteodystrophy and hormone abnormalities [1, 20,23], although the precise mechanisms are unknown. Some investigators have suggested that the GH and IGF-1 are important factors in growth retardation due to the growth of bones in human patients with CRF $[9,23]$. However, serum GH and IGF-1 concentrations are unknown in cattle with RTD. To elucidate the cause of growth retardation, we determined serum GH and IGF-1 concentrations in cattle with RTD, and analyzed GH concentrations using a computer program for analysis of episodic hormone secretion [16].

\section{MATERIALS AND METHODS}

Cattle: Fourteen Japanese Black cattle (2 males and 12 females, aged 6 to 28 months old) with RTD diagnosed by detection of a deletion of the paracellin-1 gene [17] were used (RTD group). All cattle showed growth retardation in spite of a relatively normal appetite. As controls, 6 normal Japanese Black cattle ( 2 males and 4 females, aged from 5 to

\footnotetext{
* Correspondence to: Kitagawa, H., Laboratory of Veterinary Internal Medicine, Department of Veterinary Medicine, Faculty of Applied Biological Sciences, Gifu University, 1-1 Yanagido, Gifu 501-1193, Japan.
}

11 months) were used for determinations of serum GH concentrations, and 29 cattle (14 males and 15 females, aged from 6 months to 28 months) for serum IGF-1 concentrations. On the sampling day, cattle were fed only at 16:00 hr, and given water ad libitum.

Blood and biochemical analysis: Blood samples collected at 09:00 hr were used. Routine hematology and biochemical values were obtained using an automated blood cell counter (Celltac MEK 5150; Nihon Kohden, Tokyo), a microhematocrit method, and the dry chemistry method (FDC-5500V and FDC-800V, Fuji Film, Tokyo).

Serum $G H$ and $I G F-1$ concentrations: Blood samples were obtained from the jugular vein from 09:00 hr for $10 \mathrm{hr}$ at 15 -min intervals. The sera were stored at $-70^{\circ} \mathrm{C}$. Serum $\mathrm{GH}$ concentration was estimated by radioimmunoassay [15]. Its baseline concentration, amplitude, duration, frequency, and intervals between peaks were analyzed using the PULSAR program for computer analysis of episodic hormone secretion [16]. The area under the curve of serum $\mathrm{GH}$ concentrations per hour $\left(\mathrm{AUC}_{0}\right)$ and the area under the curve above the baseline concentrations of serum GH per hour $\left(\mathrm{AUC}_{\mathrm{b}}\right)$ were calculated using a computer program for the analysis of drug pharmacokinetics [25].

Serum IGF-1 concentration was estimated for the first blood sample collected at 09:00 hr. Since the amino acid sequence of bovine and human IGF-1 is identical [10], the estimation was carried out using an immunoradiometric assay used in human diagnostics (Somatomedin C II Bayer, Yuka Medias, Ibaraki, Japan).

Statistical analysis: Data are expressed as the mean and standard deviation. Differences between the values for RTD and control groups were analyzed by the Mann-Whitney test. Correlations between serum GH or IGF-1 concentrations and other test results were determined by Spearman's rank correlation coefficient. $\mathrm{P}<0.05$ was used 
Table 1. Blood and biochemical test results

\begin{tabular}{|c|c|c|c|}
\hline \multirow[b]{2}{*}{ Variable } & Control group $(n=6)$ & RTD group (n=14) & \multirow[b]{2}{*}{$P<$} \\
\hline & Mean \pm SD & Mean \pm SD & \\
\hline $\operatorname{RBC}\left(10^{3} / \mu l\right)$ & $8610 \pm 1934$ & $7184 \pm 1799$ & NS \\
\hline Hemoglobin $(\mathrm{g} / l)$ & $113.8 \pm 8.3$ & $100.6 \pm 21.5$ & NS \\
\hline Hematocrit $(\%)$ & $34.3 \pm 3.0$ & $30.3 \pm 5.6$ & NS \\
\hline $\mathrm{WBC}\left(10^{2} / \mu l\right)$ & $80.3 \pm 19.5$ & $94.9 \pm 28.6$ & NS \\
\hline Sodium $(\mathrm{mmol} / \mathrm{l})$ & $142.0 \pm 2.3$ & $137.3 \pm 6.5$ & NS \\
\hline Potassium $(\mathrm{mmol} / l)$ & $3.9 \pm 0.3$ & $4.8 \pm 0.6$ & 0.01 \\
\hline Calcium $(\mathrm{mg} / \mathrm{d} l)$ & $9.9 \pm 0.7$ & $9.9 \pm 1.4$ & NS \\
\hline Inorganic phosphorus $(\mathrm{mg} / \mathrm{d} l)$ & $7.4 \pm 1.3$ & $7.7 \pm 1.8$ & NS \\
\hline Chloride $(\mathrm{mmol} / l)$ & $101.3 \pm 2.1$ & $95.7 \pm 5.9$ & 0.05 \\
\hline Urea nitrogen $(\mathrm{mg} / \mathrm{d} l)$ & $13.7 \pm 3.7$ & $63.8 \pm 45.0$ & 0.01 \\
\hline Creatinine $(\mathrm{mg} / \mathrm{d} l)$ & $1.3 \pm 0.3$ & $4.1 \pm 2.4$ & 0.01 \\
\hline Total cholesterol $(\mathrm{mg} / \mathrm{d} l)$ & $94.3 \pm 38.6$ & $162.0 \pm 35.9$ & 0.01 \\
\hline Glucose $(\mathrm{mg} / \mathrm{d} l)$ & $69.0 \pm 9.6$ & $89.5 \pm 19.7$ & 0.05 \\
\hline Total protein $(\mathrm{g} / \mathrm{d} l)$ & $6.4 \pm 3.6$ & $6.8 \pm 0.6$ & NS \\
\hline $\operatorname{Albumin}(\mathrm{g} / \mathrm{d} l)$ & $2.9 \pm 0.2$ & $3.3 \pm 0.4$ & 0.05 \\
\hline Aspartate aminotransferase $(\mathrm{U} / l)$ & $67.8 \pm 3.6$ & $113.1 \pm 81.8$ & NS \\
\hline Alkaline phosphatase $(\mathrm{U} / l)$ & $256.8 \pm 73.8$ & $349.1 \pm 150.6$ & NS \\
\hline
\end{tabular}

P: Probability of significant difference between the control and RTD groups. NS: Not significant.

as the level of significance.

\section{RESULTS}

Routine blood and biochemical parameters: The results are summarized in Table 1. Serum potassium, urea nitrogen (UN), creatinine (CRE), total cholesterol, glucose and albumin concentrations were significantly higher, and serum chloride concentration was significantly lower, in the RTD group than in the control group.

Serum GH concentrations: Figure 1 shows typical patterns of serum GH concentrations in healthy and RTD cattle, and Table 2 shows the results of the PULSAR program analysis. The baseline concentration in cattle of the RTD group tended to be higher than in cattle of the control group. The peak amplitude and maximum concentrations were significantly higher in cattle of the RTD group. The peak frequency was not significantly different between the normal and RTD groups. The $\mathrm{AUC}_{0}$ and $\mathrm{AUC}_{\mathrm{b}}$ were higher in cattle of the RTD group.

Serum IGF-1: Serum IGF-1 concentrations ordered with monthly ages in cattle of the normal and RTD groups are shown in Fig. 2. Serum IGF-1 concentrations were within normal ranges or slightly lower in cattle of the RTD group. Serum IGF-1 concentrations were correlated with monthly ages $(\mathrm{n}=14, \mathrm{r}=0.612, \mathrm{P}<0.02)$, body weight $(\mathrm{n}=14, \mathrm{r}=0.831$, $\mathrm{P}<0.01)$ and chest girth $(\mathrm{n}=14, \mathrm{r}=0.859, \mathrm{P}<0.01)$, but did not correlate with serum $\mathrm{GH}$ concentration $(\mathrm{n}=14, \mathrm{r}=0.123)$ and serum creatinine concentration $(n=14, r=0.532)$ in cattle with RTD (Table 3).

\section{DISCUSSION}

Secretion of GH from the pituitary gland is controlled mainly by 2 hormones, growth hormone-releasing hormone
(GHRH), which plays a role in occurrences of peak excretion, and somatotropin release-inhibiting factor (SRIF), which acts to suppress the GH excretion at the trough of GH concentration $[2,10,24]$. Blood GH concentrations were normal or high in humans [8, 9, 21, 22] and rats [7] with CRF, as well as in cattle with RTD of the present study. In human patients with CRF, the baseline concentration of serum GH was increased, but the peak amplitude and maximum concentration were normal. Therefore, $\mathrm{AUC}_{0}$ was increased, whereas $\mathrm{AUC}_{\mathrm{b}}$ was not, and it is considered that decrease in SRIF action was one of the causes of the elevated baseline concentration [13]. In cattle with RTD, however, the baseline concentration, peak amplitude, and maximum concentration of serum $\mathrm{GH}$ increased, resulting in increases in $\mathrm{AUC}_{0}$ and $\mathrm{AUC}_{\mathrm{b}}$. The increase in peak amplitude was observed simultaneously with an increase in the baseline concentration, suggesting a decrease in the action of SRIF and an increase in the action of GHRH. Moreover, the baseline concentration was not significantly correlated with peak amplitude in the RTD group, so separate factors may influence the decrease in the action of SRIF and the increase in the action of GHRH in cattle with RTD.

Serum IGF-1 concentrations and serum GH concentrations have a significant correlation in normal cattle [11]. Cattle in the RTD group, however, had normal or lower serum IGF-1 concentrations in spite of normal or higher serum GH concentrations, indicating GH resistance. Causes of $\mathrm{GH}$ resistance have been shown to be malnutrition $[3,5]$, parasitic diseases [6], liver diseases, and molecular defects of $\mathrm{GH}$ and $\mathrm{GH}$ receptors [11], as well as renal failure [9, 21]. In human patients with $\mathrm{CRF}$, it is considered that $\mathrm{GH}$ resistance may be due to reduced numbers of GH receptors in the liver (decrease in GH sensitivity) [23], and an increase in plasma concentrations of IGF binding protein (IGFBP). This indicates that CRF is associated with GH resistance in 


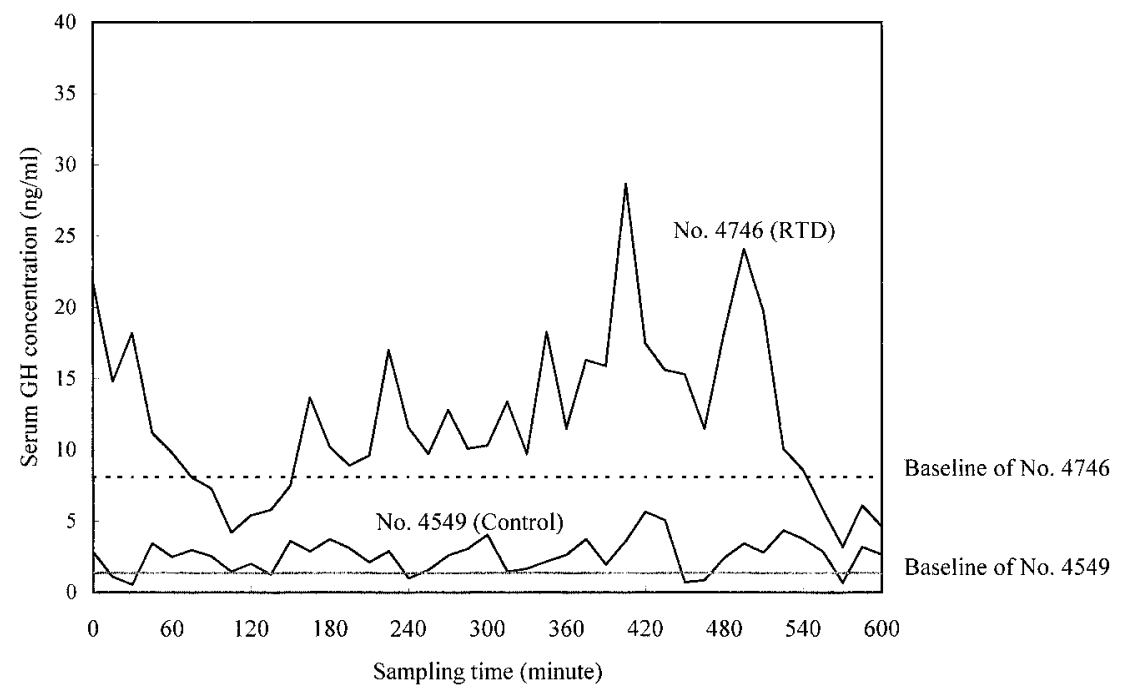

Fig. 1 Serum GH concentrations in a control animal (No. 4549) and an animal with RTD (No. 4746).

Table 2. Serum growth hormone parameters analysed by the PULSAR program

\begin{tabular}{|c|c|c|c|c|c|c|c|c|c|c|}
\hline Group & $\begin{array}{l}\text { Cattle } \\
\text { number }\end{array}$ & $\begin{array}{l}\text { Baseline } \\
\text { concentration } \\
(n \mathrm{~g} / \mathrm{m} l)\end{array}$ & $\begin{array}{c}\text { Peak } \\
\text { amplitude } \\
(n \mathrm{~g} / \mathrm{m} l)\end{array}$ & $\begin{array}{c}\text { Peak } \\
\text { duration } \\
\text { (min/l peak) }\end{array}$ & $\begin{array}{c}\text { Peak } \\
\text { frequency } \\
\text { (peak/min) }\end{array}$ & $\begin{array}{l}\text { Peak } \\
\text { interval cc } \\
(\mathrm{min})\end{array}$ & $\begin{array}{l}\text { Maximum } \\
\text { concentration } \\
(n \mathrm{~g} / \mathrm{m} l)\end{array}$ & $\underset{(n \mathrm{~g} \cdot \mathrm{min} / \mathrm{m} l)}{\mathrm{AUC}_{0}}$ & $\underset{(n \mathrm{~g} \cdot \min / \mathrm{m} l)}{\mathrm{AUC}_{\mathrm{b}}}$ & $\begin{array}{l}\text { Classifi- } \\
\text { cation }\end{array}$ \\
\hline RTD & 4665 & $6.27 \pm 2.80$ & $24.86 \pm 22.57$ & $36.0 \pm 39.1$ & 0.0167 & $67.5 \pm 31.2$ & 67.4 & 891 & 569 & B \\
\hline \multirow[t]{13}{*}{$(n=14)$} & 4666 & $3.95 \pm 2.56$ & $31.54 \pm 56.19$ & $25.7 \pm 11.3$ & 0.0233 & $50.0 \pm 18.2$ & 160.0 & 938 & 716 & B \\
\hline & 4711 & $5.55 \pm 1.33$ & $7.50 \pm 2.54$ & $27.0 \pm 26.8$ & 0.0167 & $75.0 \pm 71.4$ & 14.7 & 478 & 175 & $\mathrm{C}$ \\
\hline & 4712 & $3.83 \pm 0.75$ & $11.93 \pm 0$ & $60.0 \pm 0.0$ & 0.0033 & $0.0 \pm 0.0$ & 16.8 & 313 & 121 & B \\
\hline & 4713 & $5.32 \pm 2.59$ & $4.55 \pm 1.51$ & $30.0 \pm 15.0$ & 0.0100 & $120.0 \pm 42.4$ & 14.6 & 388 & 99 & $\mathrm{C}$ \\
\hline & 4714 & $3.57 \pm 1.05$ & $2.86 \pm 1.95$ & $15.0 \pm 0.0$ & 0.0067 & $150.0 \pm 0$ & 8.1 & 219 & 31 & $\mathrm{C}$ \\
\hline & 4718 & $6.10 \pm 1.09$ & $4.51 \pm 1.89$ & $20.0 \pm 8.7$ & 0.0100 & $150.0 \pm 84.9$ & 12.7 & 396 & 70 & $\mathrm{C}$ \\
\hline & 4745 & $5.92 \pm 1.55$ & $22.73 \pm 26.33$ & $72.5 \pm 39.6$ & 0.0100 & $117.0 \pm 30.7$ & 76.2 & 660 & 319 & B \\
\hline & 4746 & $8.08 \pm 3.47$ & $10.47 \pm 6.34$ & $53.6 \pm 43.2$ & 0.0117 & $97.5 \pm 40.0$ & 28.7 & 733 & 279 & A \\
\hline & 4853 & $5.68 \pm 3.13$ & $16.76 \pm 5.22$ & $93.8 \pm 14.4$ & 0.0067 & $190.0 \pm 95.3$ & 31.1 & 627 & 327 & B \\
\hline & 4861 & $13.80 \pm 8.08$ & $20.63 \pm 18.76$ & $39.0 \pm 22.8$ & 0.0083 & $116.3 \pm 61.7$ & 63.6 & 1067 & 413 & A \\
\hline & 4866 & $13.12 \pm 9.33$ & $13.05 \pm 5.04$ & $80.0 \pm 31.2$ & 0.0050 & $120.0 \pm 84.9$ & 39.3 & 841 & 233 & A \\
\hline & 4867 & $12.83 \pm 4.38$ & $25.66 \pm 5.45$ & $100.0 \pm 22.9$ & 0.0050 & $232.5 \pm 137.9$ & 47.4 & 1111 & 462 & A \\
\hline & 5088 & $2.25 \pm 2.07$ & $5.86 \pm 4.29$ & $55.0 \pm 58.2$ & 0.0100 & $120.0 \pm 64.5$ & 16.9 & 271 & 168 & $\mathrm{C}$ \\
\hline Mean \pm standard & deviation & $6.88 \pm 3.74$ & $14.49 \pm 9.26^{* *}$ & $50.5 \pm 27.6$ & $0.0103 \pm 0.0057$ & $114.3 \pm 60.2$ & $42.7 \pm 40.5^{\prime}$ & $* * 638 \pm 307 *$ & $284 \pm 200^{* *}$ & \\
\hline Control & $(\mathrm{n}=6)$ & $4.21 \pm 2.80$ & $3.79 \pm 0.89$ & $43.4 \pm 9.5$ & $0.0133 \pm 0.0020$ & $89.8 \pm 21.3$ & $10.4 \pm 3.6$ & $294 \pm 105$ & $126 \pm 40$ & \\
\hline
\end{tabular}

Data are presented as mean \pm standard deviation. $\mathrm{AUC}_{0}$ : Area under the curve per hr of serum $\mathrm{GH}_{\text {concentration. } \mathrm{AUC}}$ : area under the curve per hr of serum GH concentrations above the baseline concentration. A: Cattle with high baseline concentration and peak amplitude of serum GH. B: Cattle with normal baseline concentration and high peak amplitude of serum GH. C: Cattle with normal baseline concentration and peak amplitude of serum GH. * and **: Significantly different from values in the control group. Single and double asterisks indicate $\mathrm{P}<0.05$ and $\mathrm{P}<0.01$, respectively.

cattle with RTD, but the specific mechanisms are unknown.

Serum IGF-1 concentration correlated significantly with body weight and chest girth. These significant correlations suggest that IGF-1 might correlate with the growth of cattle with RTD. Growth retardation in cattle with RTD may be associated with $\mathrm{GH}$ resistance (abnormalities from $\mathrm{GH}$ receptors to IGF-1 synthesis), but it may not be a primary cause.
ACKNOWLEDGEMENTS. We gratefully acknowledge Dr. A.F. Parlow of NIDDK, U.S.A., for providing the GH antibody. We thank Drs. H. Tsukamura and K. Maeda, Graduate School of Bioagricultural Sciences, Nagoya University, for use of the PULSAR program. This work was supported in part by a Grant-in-Aid (Nos. 11490014 and 15380214) for Scientific Research from the Ministry of Education, Culture, Sports, Science and Technology of the Government of Japan. 


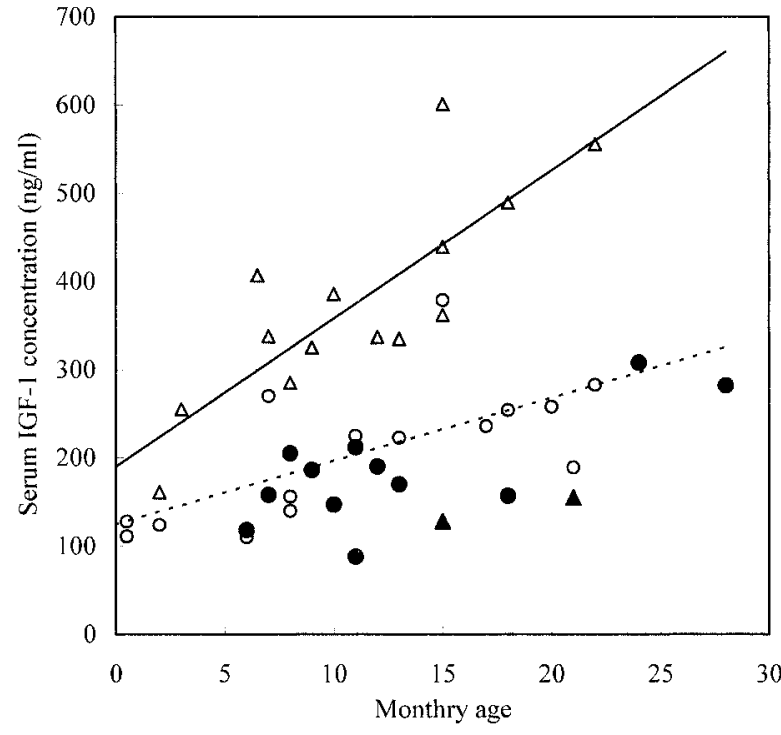

Fig. 2. Serum IGF-1 concentrations in control cattle and cattle with RTD. : Female with RTD, $\mathbf{\Delta}$ : male with RTD, $\bigcirc$ : female control, $\triangle$ : male control. - : Regression line of male controls $(\mathrm{n}=14, \mathrm{y}=16.80 \mathrm{x}+190.26, \mathrm{P}<0.01)$. -----: Regression line of female controls $(\mathrm{n}=15, \mathrm{y}=7.19 \mathrm{x}+124.68, \mathrm{P}<0.01)$.

\section{REFERENCES}

1. Bircan, Z., Kervancioglu, M., Soran, M. and Yildirim, I. 1998. Growth hormone stimulation tests in CRF with metabolic acidosis. Acta Paediatr. Jpn. 40: 70-72.

2. Borski, R. J., Tsai, W., Demott-Friberg, R. and Barkan, A. L. 2000. Induction of growth hormone (GH) mRNA by pulsatile GH-releasing hormone in rats is pattern specific. Am. J. Physiol.-Endocrinol. Metab. 278: E885-E891.

3. Breier, B. H., Bass, J. J., Butller, J. H. and Gluckman, P. D. 1986. The somatotrophic axis in young steers: influence of nutritional status on pulsatile release of growth hormone and circulating concentrations of insulin-like growth factor 1. $J$. Endocrinol. 111: 209-215.

4. Breier, B. H. 1999. Regulation of protein and energy metabolism by the somatotropic axis. Domest. Anim. Endocrinol. 17: 209-218.

5. Elasser, T. H., Rumsey, T. S. and Hammond, A. C. 1989. Influence of diet on basal and growth hormone-stimulated plasma concentrations of IGF-1 in beef cattle. J. Anim. Sci. 67: 128141.

6. Elasser, T. H., Sartin, J. L., Mcmahon, C., Romo, G., Fayer, R., Kahl, S. and Blagburn, B. 1998. Changes in somatotropic axis response and body composition during growth hormone administration in progressive cachectic parasitism. Domest. Anim. Endocrinol. 15: 239-255.

7. Finidori, J., Postel-Vinay, M. C. and Kleinknecht, C. 1980. Lactogenic and somatotropic binding sites in liver membranes of rats with renal insufficiency. Endocrinology 106: 19601965.

8. Fouque, D. 1996. Insulin-like growth factor I resistance in CRF. Mineral Electrolyte Metab. 22: 133-137.

9. Frystyk, J., Ivarsen, P., Skjarbak, C., Flyvbjerg, A., Pedersen, E. B. and Ørskov, H. 1999. Serum-free insulin-like growth fac- tor 1 correlates with clearance in patients with chronic renal failure. Kidney Int. 56: 2076-2084.

10. Gluckman, P. D., Breier, B. H. and Davis, S. R. 1987. Physiology of the somatotropic axis with particular reference to the ruminant. J. Dairy Sci. 70: 442-466.

11. Hammond, A. C., Elsasser, T. H. and Olson, T. A. 1991. Endocrine characteristics of a miniture condition in Brahman cattle: Circulating concentrations of some growth-related hormones. Proc. Soc. Exp. Biol. Med. 197: 450-457.

12. Hannon, K., Gronowski, A. and Trenkle, A. 1991. Relationship of liver and skeletal muscle IGF-1 mRNA to plasma GH profile, production of IGF-1 by liver, plasma IGF-1 concentrations, and growth rates of cattle. Proc. Soc. Exp. Biol. Med. 196: $155-163$.

13. Hokken-Koelega, A. C. S., Hackeng, W. H. L., Stijnen, T., Wit, J. M., Keizer-Schrama, S. M. P. F. M. and Drop, S. L. S. 1990. Twenty-four-hour plasma growth hormone $(\mathrm{GH})$ profiles, urinary $\mathrm{GH}$ excretion, and plasma insulin-like growth factor-I and -II levels in prepubertal children with chronic renal insufficiency and severe growth retardation. J. Clin. Endocrinol. Metab. 71: 688-695.

14. Kitagawa, H., Kitoh, K., Ito, T., Ohba, Y., Nishii, N., Katoh, K., Obara, Y., Motoi, Y. and Sasaki, Y. 2001. Serum growth hormone and insulin-like growth factor-1 concentrations in Japanese black cattle with growth retardation. J. Vet. Med. Sci. 63: $167-170$.

15. Kuhara, T., Ikeda, S., Ohneda, A. and Sasaki, Y. 1991. Effect of intravenous infusion of 17 amino acids on the secretion of GH, glucagon, and insulin in sheep. Am. J. of Physiol. 260: E21-E26.

16. Merriam, G. R. and Wachter, K. W. 1982. Algorithms for the study of episodic hormone secretion. Am. J. Physiol. 243: E310-E318.

17. Ohba, Y., Kitagawa, H., Kitoh, K., Sasaki., Y., Takami, M., Shinkai, Y. and Kunieda, T. 2000. A deletion of the paracellin1 gene is responsible for renal tubular dysplasia in cattle. Genomics 68: 229-236.

18. Ohba, Y., Kitagawa, H., Kitoh, K., Oikawa, T. and Sasaki, Y. 2001. Inheritance of renal tubular dysplasia in Japanese black cattle. Vet. Rec. 149: 153-154.

19. Ohba, Y., Kitagawa, H., Okura, Y., Kitoh, K. and Sasaki, Y. 2001. Clinical features of renal tubular dysplasia, a new hereditary disease in Japanese black cattle. Vet. Rec. 149: 115-118.

20. Postel-Vinay, M C., Tar, A., Crosnier, H., Broyer, M., Rapparort, R. and Tonshoff, B. 1991. Serum growth hormone binding protein is low in uremic children. Pediatr. Nephrol. 5: 545547.

21. Santos, F., Orejas, G., Rey, C., Garcia-Vicente, S. and Malaga, S. 1991. Growth hormone metabolism in uremia. Child Nephrol. Urol. 11: 130-133.

22. Styne, M. 2001. Growth. pp. 163-200. In: Basic and Clinical Endocrinology. 6th ed. (Greenspan, F. S. and Gardner, D. G. eds.) Lange Medical Books/McGraw Hill, New York.

23. Tonshoff, B., Blum, W. F. and Mehls, O. 1997. Derangements of the somatotropic hormone axis in chronic renal failure. Kidney Int. 58: 106-113.

24. Wagner, C., Caplan, S. R. and Tannenbaum, G. S. 1998. Genesis of the ultradian rhythm of GH secretion: a new model unifying experimental observations in rats. Am. J Physiol.Endocrinol. Metab. 38: E1046-E1054.

25. Yamaoka, K. and Tanikawara, Y. 1983. A Guidebook of Pharmacokinetics Using a Microcomputer. Nankodo, Tokyo (in Japanese). 